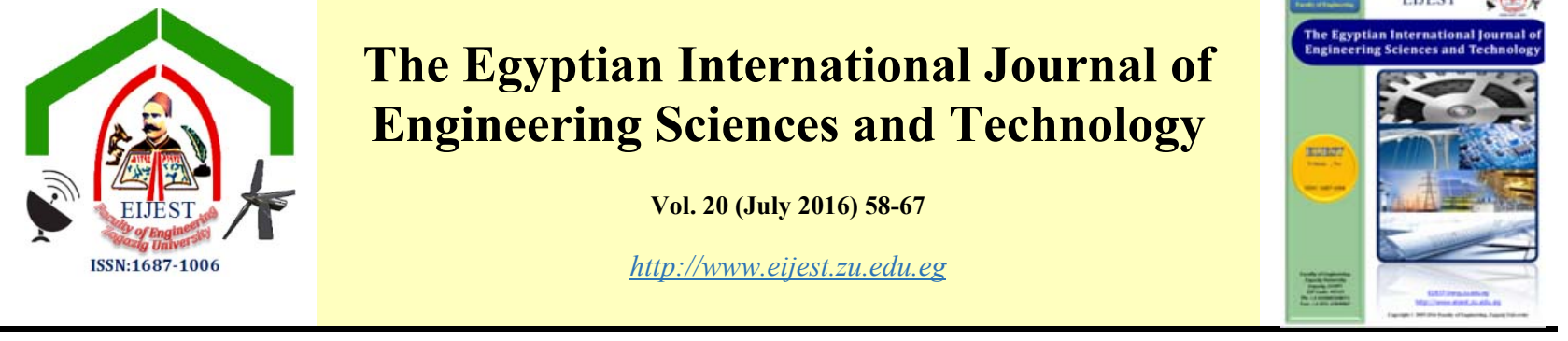

\title{
Identifying and Assessing Supply Chain Risks Depending on Product Variety
}

\author{
Abdel Nasser H. Zaied ${ }^{\mathrm{a}}$, Mohamed A. Mansour ${ }^{\mathrm{b}}$, and Doaa A. AbdelNaieem ${ }^{\mathrm{b}}$ \\ ${ }^{a}$ Professor, Dean, collage of computer and informatics, Zagazig University, Zagazig, Egypt \\ ${ }^{b}$ Department of Industrial Engineering, Faculty of Engineering, Zagazig University, Zagazig, Egypt
}

\begin{tabular}{|c|c|}
\hline A R T I CLE I N F O & A B S T RAC T \\
\hline $\begin{array}{l}\text { Article history: } \\
\text { Received: } 21 \text { March } 2016 \\
\text { Received in revised form: } 28 \\
\text { May } 2016 \\
\text { Accepted: } 19 \text { June } 2016 \\
\text { Available online: } 16 \text { July } \\
2016\end{array}$ & $\begin{array}{l}\text { Companies always trying to increase market share and profits by increasing } \\
\text { customer satisfaction through the variety in the products they offer. However, at the } \\
\text { same time, the Product variety brought many challenges to manufacturing systems } \\
\text { and supply chains. Product variety could make a supply chain more exposed to } \\
\text { various types of disruptions. There are always associated opportunity risks when } \\
\text { variety products. Risk can be defined as the uncertainty of an event occurring that }\end{array}$ \\
\hline $\begin{array}{l}\text { Keywords: } \\
\text { Supply Chain (SC) } \\
\text { Risk Management (RM) } \\
\text { Supply Chain Risk } \\
\text { Management (SCRM) } \\
\text { Product Variety (PV) } \\
\text { Risk Identification } \\
\text { Risk Assessment } \\
\text { Fuzzy Analytical Hierarchy } \\
\text { Process (FAHP). }\end{array}$ & $\begin{array}{l}\text { supply chain management is supply chain risk management. Risk management can't } \\
\text { be done without define the risks then prioritize them to mitigate the most important } \\
\text { risks. This paper helps in identifying and assessing the potential risks that are likely } \\
\text { to disrupt a supply chain when variety products. All product variety risks gathered } \\
\text { based on the previous researches of the effect of product variety on the supply } \\
\text { chain from } 1985 \text { until } 2014 \text {. The risks grouped under five basic dimensions of } \\
\text { supply chain (Marketing, Logistic, Manufacturing, Engineering, and purchasing). } \\
\text { Then the risks prioritized using Fuzzy Analytical Hierarchy process (FAHP). }\end{array}$ \\
\hline
\end{tabular}

\section{Introduction}

Recently to gain more market share, companies are increasing variety in their products where customers' preferences to products change rapidly and customers would like to buy just what they need. By increasing product variety (PV) in style, function, package, size, and so on, it may be possible to satisfy customers more, resulting in enhanced competitiveness and more market share in the market. Even though increasing product variety might increase sales, it has drawbacks so that it might not be profitable. Thus, a challenge faced by companies today is to offer variety in order to satisfy customer's needs while managing the product variety risks.

Increasing product variety might have strong effect on the supply chain (SC). However, more product variety may increase the manufacturing costs and complexity. Increasing product variety causes 
higher complexity of demand forecasting and matching of supply with demand in the supply chain (Whang and Lee, 1998; Randall and Ulrich, 2001; Desai, K. and Trivedi, M., 2014). Therefore, companies increasing variety in their product lines should also understand the effect of product variety on all relevant costs and the various functions performed by the supply chain.

All the previous changes increase the importance of supply chain risk management (SCRM). Hopkin (2014) defines Risk management as "Actions taken to reduce the likelihood and/or magnitude of a risk". Risk management provides a framework for organizations to deal with and to react to uncertainty. While the Institute of Internal Auditors (IIA) defines risk as the uncertainty of an event occurring that could have an impact on the achievement of objectives.

Effective management of risks is becoming the focal concern of the firms to survive and thrive in a competitive business environment. Thus the supply chain risk management (SCRM) has emerged as a natural extension of supply chain management with the prime objective of identifying the potential sources of risks and suggesting suitable action plans to mitigate them (Singhal, P. et al, 2011). A typical process of risk management contains three basic steps (Manuj and Mentzer, 2009 and Mody, A., 2012): (i) Risk identification, (ii) Risk Assessment, (iii) Risk Mitigation.

Risk identification is the first stage of risk management. It develops the basis for the next steps: assessment and mitigation of risk management (Tchankova, L., 2002). Correct risk identification ensures risk management effectiveness. The second step is the risk assessment which refers to assign weights to risks and determine the priority of these risks that defined in the first step to be mitigated in the third step. It is difficult to response to all risks in the same time, so prioritize risks is a basic procedure in risk management.

The previous background provides the motivation to investigate and assess the product variety risks in the supply chain. The objective of this research is to define and assess the important risks of product variety in the supply chain. The procedures of the research are shown in "Figure 1".
Identify the basic dimensions of SC

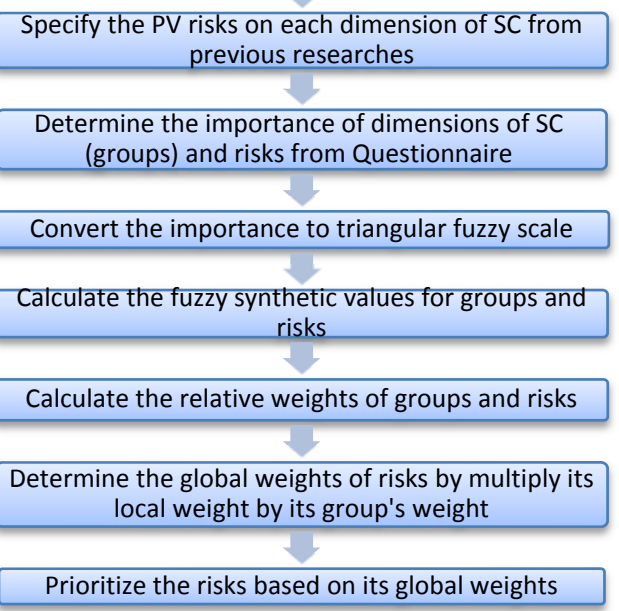

Fig. 1. The research's procedures

\section{Literature Review}

Thönemann and Bradley (2002) assert that high product variety impairs supply chain performance. Several functions in the supply chain have directly related to product variety, as illustrated in "Figure 2" (Park, T. et al., 2004). Marketing department in a firm plays a main role to determine the customer's needs. However, percentage of publications of the effect of product variety on each dimension of the supply chain is indicated in "Figure 3".

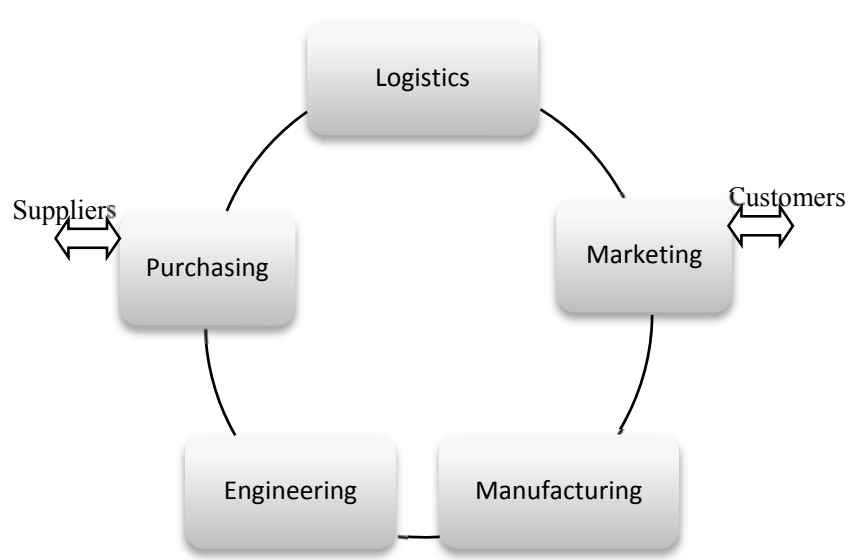

Fig. 2. Supply chain functions affected by product variety 


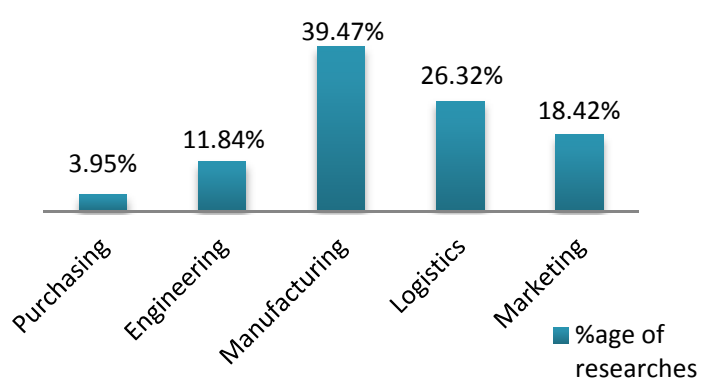

Fig.3. Percentage of publication of PV in each dimension of SC

Product variety has long been used to increase firm performance (Wan, X., 2011). However, greater product variety does not always lead to higher sales. For example, when Procter \& Gamble Co. reduced the number of versions of its Head and Shoulders shampoo from 26 to 15, sales actually increased ten percent (Wan, X., 2011).

Offering products, which do not satisfy the customer needs, might not increase the market share, but might adversely affect the costs. Marketers have to be careful in assessing the customers' needs, since, increasing product variety increases the costs and complexity in manufacturing (Alford et al., 2000; $\mathrm{Hu}$, S.J. et al., 2008; ElMaraghy, H. et al., 2013). Higher product variety also evokes the complexity of demand forecasting and matching of supply with demand in the supply chain.

Increasing variety has effect on various logistics operations and costs. Variety incurs many indirect costs, such as raw material costs, work-in-process (WIP), finished goods, and post-sales service inventories, and logistics costs that are difficult to capture, and are often neglected when making the decision about introducing variety (Martin and Ishii, 1996). Due to the uncertainty in forecasting demands, a firm offering more variants usually tends to carry more finished goods inventory than a firm with less variants.

Increase in variety increases the inventory levels and inventory costs (Fisher and Ittner, 1999; Thonemann and Bradley, 2002; Ton, Z. and Raman, A., 2010). Increasing variety also increases the inventories of purchased and semi-finished parts (Forza and Salvador, 2001). Benjaafar, et al. (2002) examined the effect of product variety on inventoryrelated costs, and showed that total cost increases linearly with the number of products. De Groote, X. and Yücesan, E.(2011) show that keeping the total demand constant, the expected cost of inventories and backorders increases linearly with the number of products. Er and MacCarthy (2006) asserted that increasing variety alone does not have a significant impact on the average of total inventory. They stated that the average of total inventory is affected highly by the uncertainty in supply delivery time.

Increasing variety increases the inventories of purchased and semi-finished parts (Forza and Salvador, 2002). As the product variety increases the variety in purchased parts and materials also increases (Fisher et al., 1999; Forza and Salvador, 2002). Increase in part/ material variety may lead to uncertainty in delivery times (Fisher and Ittner, 1999).

Increase in variety increases the purchasing costs (Randall and Ulrich, 2001. Also, Increasing variety increases the design workload connected to the development of numerous product variants (Forza and Salvador, 2002; Desai, K. and Trivedi, M., 2014. Also, increasing product variety increases the costs and complexity in manufacturing (Alford et al., 2000; Hu, S.J. et al., 2008; Desai, K. and Trivedi, M., 2014). As product variety increases, the performance of the firm's internal operations decreases due to higher direct manufacturing costs, manufacturing overhead, delivery times, and inventory levels (Forza and Salvador, 2002).

Increasing the variety level also generates a range of difficulties in ensuring operational efficiency (McCutcheon et al., 1994; Åhlström, P. and Westbrook, R., 1999). A broader product line with corresponding low volumes for each item in the line can result in higher unit costs, mainly because of increases in overhead expenses (Park, T. et al., 2004; Hayes and Wheelright, 1984), and higher direct labor and material costs (Park, T. et al., 2004; Abbegglen and Stalk, 1985).Especially, if setup times are significant, the effect of product variety on cost is substantially greater than that suggested by the riskpooling literature for perfectly flexible manufacturing processes (Thonemann and Bradley, 2002).

Banker et al. (1990) studied an auto component manufacturer and observed that product complexity had a significant impact on the cost of supervision, quality control, and tool maintenance. Increasing product variety within a supply chain increases both production costs (Park, T. et al., 2004; Stalk and Hout, 1990; Cooper and Kaplan, 1990) and market mediation costs (Fisher et al., 1999).

Although product variants risks have a major impact in the supply chain, no one of the surveyed researches is interested in managing the product variety risks (Thun, J.H. and Hoenig, D., 2011). Or, at least, gather all the product variety risks and determine the most important risks to be able to mitigate them. So, this study helps in filling the gap in the literature. In this paper all product variety risks will be identified in section 3 , and then assessed in section 4 . 


\section{Risk Identification}

The most significant risks of product variety are gathered from precedent product variety researches. Then the risks are grouped under the five basic dimensions of supply chain (Purchasing, Engineering, Manufacturing, Logistic, and Marketing) suggested by (Park, T. et al., 2004). The total number of risks at first was 38 but it was reduced to 11 main risks after a depth interview with supply chain managers of sixty industries to eliminate excess risks that depend on main risks. The product variety risks in each dimension of the supply chain, the definition of each risk, and the researchers studied the effect of these risks on the supply chain, are shown in "Table 1 ".

Table 1. Product variety risks

\begin{tabular}{|c|c|c|}
\hline Risks & Definition & Researches \\
\hline \multicolumn{3}{|l|}{ Purchaing } \\
\hline $\begin{array}{l}\text { Increasing } \\
\text { purchasing } \\
\text { costs }\end{array}$ & $\begin{array}{lr}\text { Product } & \text { variety } \\
\text { exacerbates purchasing } \\
\text { costs when volume is } \\
\text { divided into multiple } \\
\text { products such that quantity } \\
\text { discounts in purchasing } \\
\text { are impossible. }\end{array}$ & $\begin{array}{l}\text { Ulrich and } \\
\text { Randall, } 2001\end{array}$ \\
\hline $\begin{array}{l}\text { Increasing the } \\
\text { lead time }\end{array}$ & $\begin{array}{l}\text { The length of time } \\
\text { required by a supplier to } \\
\text { deliver the material to the } \\
\text { manufacturer, and it } \\
\text { subject to uncertainty. }\end{array}$ & Er, M. (2004) \\
\hline \multicolumn{3}{|l|}{ Engineering } \\
\hline $\begin{array}{l}\text { Increasing the } \\
\text { complexity in } \\
\text { design }\end{array}$ & $\begin{array}{l}\text { Product families with high } \\
\text { product variety level and } \\
\text { low production volume } \\
\text { tend to be more complex } \\
\text { than product families with } \\
\text { low product variety level } \\
\text { and high production } \\
\text { volume. }\end{array}$ & $\begin{array}{lr}\text { Zhenxin } & \text { Yu } \\
\text { (2006); Forza and } \\
\text { Salvador, 2002; } \\
\text { Kalpesh and } \\
\text { Minakshi, 2014; } \\
\text { S.J. Hu et al., } \\
\text { 2008; Xiaowei } \\
\text { Zhu, 2009; Hui } \\
\text { Wang, 2010 }\end{array}$ \\
\hline \multicolumn{3}{|l|}{ Manufacturing } \\
\hline $\begin{array}{l}\text { Quality ( } \\
\text { increasing } \\
\text { control costs } \\
\text { or reworks) }\end{array}$ & $\begin{array}{l}\text { Greater parts variety implies } \\
\text { lower volume per part, so, } \\
\text { statistical process control } \\
\text { becomes harder to perform } \\
\text { when demand for parts is } \\
\text { low and episodic, which } \\
\text { increasing quality problems. }\end{array}$ & $\begin{array}{l}\text { G. Scott Webb } \\
(2011) \text {; Hesna } \\
\text { Muge Yayla- } \\
\text { Kullu (2009), } \\
\text { Zhenxin Yu } \\
\text { (2006), Banker } \\
\text { et al., 1990 }\end{array}$ \\
\hline $\begin{array}{l}\text { Increasing } \\
\text { set-up time }\end{array}$ & $\begin{array}{l}\text { Setup time is the period } \\
\text { required to prepare a device, } \\
\text { machine, process, or } \\
\text { system to be ready } \\
\text { to function or accept a job. }\end{array}$ & $\begin{array}{l}\text { Er, M., 2004, } \\
\text { Yeh and Chu, } \\
\text { 1991, Fisher and } \\
\text { Ittner,1999; } \\
\text { Susan, 2006 }\end{array}$ \\
\hline $\begin{array}{l}\text { Increasing } \\
\text { manufacturing } \\
\text { complexity }\end{array}$ & $\begin{array}{l}\text { A complex system is one, } \\
\text { which has many numbers of } \\
\text { parts, which their } \\
\text { relationships are not simple. }\end{array}$ & $\begin{array}{l}\text { Alford et al., } \\
2000 ; \text { Yeh and } \\
\text { Chu, 1991 }\end{array}$ \\
\hline
\end{tabular}

Table 1(continue). Product variety risks

\begin{tabular}{|c|c|c|}
\hline Risks & Definition & Researches \\
\hline \multicolumn{3}{|l|}{ Logistics } \\
\hline $\begin{array}{l}\text { Increasing } \\
\text { the WIP }\end{array}$ & $\begin{array}{l}\text { Work in process inventory } \\
\text { means partially completed } \\
\text { goods, parts, or sub- } \\
\text { assemblies. }\end{array}$ & $\begin{array}{l}\text { Yeh and Chu, 1991; } \\
\text { Trivikarm H Rao } \\
(2008)\end{array}$ \\
\hline $\begin{array}{l}\text { Increasing } \\
\text { the } \\
\text { inventory } \\
\text { level }\end{array}$ & $\begin{array}{l}\text { The current amount of } \\
\text { a product that } \\
\text { a company has in stock. }\end{array}$ & $\begin{array}{l}\text { Anderson, 1995; } \\
\text { Fisher and Ittner, } \\
\text { 1999; Forza and } \\
\text { Salvador, 2002; Miller } \\
\text { and Vollmann, 1985; } \\
\text { Fisher et al., 1995; } \\
\text { Xavier de Groote and } \\
\text { Enver Yücesan 2011; } \\
\text { Zeynep and Ananth, } \\
2010\end{array}$ \\
\hline $\begin{array}{l}\text { Increasing } \\
\text { the market } \\
\text { mediation } \\
\text { cost }\end{array}$ & $\begin{array}{l}\text { Includes the variety- } \\
\text { related inventory holding } \\
\text { costs and shortage costs. }\end{array}$ & Fisher et al., 1996 \\
\hline $\begin{array}{l}\text { Increasing } \\
\text { the } \\
\text { material } \\
\text { handling } \\
\text { cost }\end{array}$ & $\begin{array}{l}\text { The movements of } \\
\text { materials to, through, and } \\
\text { from productive processes } \\
\text { in warehouses and } \\
\text { storage, and in receiving } \\
\text { and shipping areas. }\end{array}$ & $\begin{array}{l}\text { Yeh and Chu 1991; } \\
\text { Fisher et al., 1995; } \\
\text { Abegglen and Stalk, } \\
1985\end{array}$ \\
\hline \multicolumn{3}{|l|}{ Marketing } \\
\hline $\begin{array}{l}\text { Increasing } \\
\text { the } \\
\text { Demand } \\
\text { uncertainty }\end{array}$ & $\begin{array}{l}\text { There is a difficulty } \\
\text { accurately forecast } \\
\text { customer demand in the } \\
\text { future. }\end{array}$ & $\begin{array}{l}\text { Kalpesh and } \\
\text { Minakshi, 2014; } \\
\text { Zhenxin Yu 2006; Er, } \\
\text { M. (2004); Ulrich and } \\
\text { Randall, 2001; Er and } \\
\text { MacCarthy, 2003; } \\
\text { Fisher et al., 1995 }\end{array}$ \\
\hline
\end{tabular}

\section{Risk Assessment}

It is difficult to respond to all risks in the same time. So, prioritize risks is a basic procedure in risk management to define which risks should be mitigated. In this study, Fuzzy Analytic Hierarchy Process (FAHP) which is considered as one of the most popular decision making techniques is used to estimate the weights of the risks in a supply chain to prioritize them. The analytic hierarchy process (AHP) is a multi-criteria decision-making tool that can handle unstructured or semi-structured decisions with multi-person and multi-criteria inputs. AHP includes the basics of decomposition, pair-wise comparisons, and priority vector generation and synthesis.

Although AHP is based on expert's opinion; traditional approach of the method can not reflect the human mind in a realistic way (Faisal, 2010). In the traditional AHP technique, it is suspicious to use integer values while the alternatives are compared to each other. Besides, judgment scale in this method is criticized for not being capable of understanding the uncertainties and negligence in the comparison process (Sofyalığlu and Kartal, 2012). In order to 
eliminate these shortcomings, FAHP method will be used.

FAHP can be seen as a synthetic extension of the traditional AHP method by taking into account the fuzziness of decision maker. In order to show how calculations are made, the basic steps of this method are described as follows (Sofyalığlu and Kartal, 2012):

1. A hierarchical structure is created by defining multi-criteria decision problem. The structure consists of an overall objective, alternatives to reach to the objective and criteria that relate the alternatives to the objective.

2. Expert's opinion is very critical in the solving of this decision problem. So, a questionnaire is constructed containing pair-wise comparisons of criteria or alternatives and answered by the experts of the subject. These pair-wise comparisons are diverted to a comparison matrix through a preference scale developed by Wind and Saaty (1980). Because of the fact that uncertainty should be considered in some or all of the pair-wise comparison values, the pair-wise comparison under traditional AHP, in which discrete values are selected in the process, may not be acceptable (Yu, 2002). Therefore, the preference scale is converted into linguistic fuzzy scale as proposed by Angnostopoulos et al., (2007). The preference scale of AHP and linguistic fuzzy scale are shown in "Table 2 " and represented in "Figure 4".

Table 2. Triangular Fuzzy linguistic scale

\begin{tabular}{|l|c|c|c|}
\hline & $\begin{array}{l}\text { Intensity } \\
\text { of } \\
\text { importa- } \\
\text { nce }\end{array}$ & $\begin{array}{l}\text { Triangular } \\
\text { fuzzy } \\
\text { scale }\end{array}$ & $\begin{array}{l}\text { Triangular } \\
\text { fuzzy } \\
\text { reciprocal } \\
\text { scale }\end{array}$ \\
\hline Equal Importance & 1 & $(1,1,1)$ & $(1,1,1)$ \\
\hline $\begin{array}{l}\text { Equal to moderate } \\
\text { importance }\end{array}$ & 2 & $(1,2,3)$ & $(1 / 3,1 / 2,1)$ \\
\hline $\begin{array}{l}\text { Moderate } \\
\text { Importance }\end{array}$ & 3 & $(2,3,4)$ & $(1 / 4,1 / 3,1 / 2)$ \\
\hline $\begin{array}{l}\text { Moderate to strong } \\
\text { importance }\end{array}$ & 4 & $(3,4,5)$ & $(1 / 5,1 / 4,1 / 3)$ \\
\hline Strong Importance & 5 & $(4,5,6)$ & $(1 / 6,1 / 5,1 / 4)$ \\
\hline $\begin{array}{l}\text { Strong to very } \\
\text { strong importance }\end{array}$ & 6 & $(5,6,7)$ & $(1 / 7,1 / 6,1 / 5)$ \\
\hline $\begin{array}{l}\text { Very strong } \\
\text { Importance }\end{array}$ & 7 & $(6,7,8)$ & $(1 / 8,1 / 7,1 / 6)$ \\
\hline $\begin{array}{l}\text { Very strong to } \\
\text { demonstrated } \\
\text { importance }\end{array}$ & 8 & $(7,8,9)$ & $(1 / 9,1 / 8,1 / 7)$ \\
\hline $\begin{array}{l}\text { Demonstrated } \\
\text { Importance }\end{array}$ & 9 & $(8,9,9)$ & $(1 / 9,1 / 9,1 / 8)$ \\
\hline
\end{tabular}

Level 1

Objective

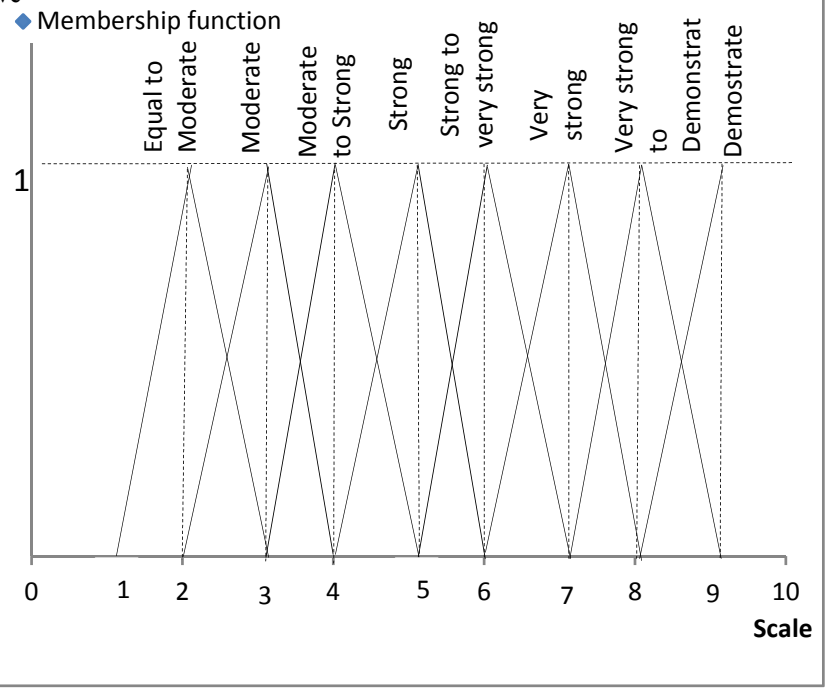

Fig. 4. Triangular Fuzzy Linguistic Scale

3. Chang, 1996, extent analysis method is used to calculate fuzzy synthetic values. This calculations are explained following:

- The triangular fuzzy number can be denoted as: $M=(l, m, u)$. Where, $(l<$ $m<u) l, m$, and $u$ stands for the lower value, mind-value, and upper value of the support of $M$, respectively. When $(l=m=u)$, it is a non fuzzy number.

- Chang's analysis method is applied for each criteria and alternative. Therefore, for each criteria or alternative (i), $k$ extent analysis values is obtained, as following:

$M_{i}^{1}, M_{i}^{2}, \ldots \ldots, M_{i}^{k}, \quad(i=1,2, \ldots, n)$, and $k=$

number of criteria or alternatives.

- Each value of $M_{i}^{j},(i=$ $1,2, \ldots, n$ and $j=1,2, \ldots, k)$ is a triangle fuzzy number. According to criteria or alternative $i$, the fuzzy synthetic value (fuzzification process) is defined as:

$$
S_{i}=\sum_{j=1}^{k} M_{i}^{j} \otimes\left[\sum_{i=1}^{n} \sum_{j=1}^{k} M_{i}^{j}\right]^{-1}
$$

Where;

$$
\sum_{j=1}^{k} M_{i}^{j}=\left(\sum_{j}^{k} l_{j}, \sum_{j}^{k} m_{j}, \sum_{j}^{k} u_{j}\right)
$$


And;

$\sum_{i=1}^{n} \sum_{j=1}^{k} M_{i}^{j}=\left(\sum_{i}^{n} l_{i}, \sum_{i}^{n} m_{i}, \sum_{i}^{n} u_{i}\right)$

Hence;

$$
\left[\sum_{i=1}^{n} \sum_{j=1}^{k} M_{i}^{j}\right]^{-1}=\left(\frac{1}{\sum_{i}^{n} u_{i}}, \frac{1}{\sum_{i}^{n} m_{i}}, \frac{1}{\sum_{i}^{n} l_{i}}\right)
$$

4. Using Wang's method, Wang et al. (2008), to estimate the relative weights of each criterion or alternative (defuzzification process). The Chang's extent analysis method estimates the final weights from the fuzzy comparison misapplications. From that, in this study, after calculating the synthetic values by Chang's method, the final weights are calculated from weighted index values of integral values according to Wang's method. The total integral value for the triangular fuzzy number is defined as following;

$I_{i}^{\alpha}(M)=\frac{1}{2} \alpha(m+u)+\frac{1}{2}(1-$
$\alpha)(1+m)=\frac{1}{2}[\alpha u+m+(1-\alpha) l]$

Where, $\alpha$ is an index of optimism which represents the degree of optimism of the decisionmaker, and $0 \leq \alpha \leq 1$. A bigger value of $\alpha$ denotes a higher degree of optimism. $l, m$, and $u$ stands for the lower value, mind-value and upper value of the Synthetic value, and $(l<m<u)$. Then, the weight of every criterion is calculated by normalizing the index of optimism using the formula of:

$$
W_{i}=\frac{I_{i}}{\sum_{i=1}^{n} I_{i}}
$$

According to the first step of the previous method, figure 5 indicates the prioritization problem. Where, the overall objective is prioritization the product variety risks. On the other hand, the departments of the supply chain can be considered as the alternative groups to reaching the objective. Moreover, criteria are the risks related to each alternative.

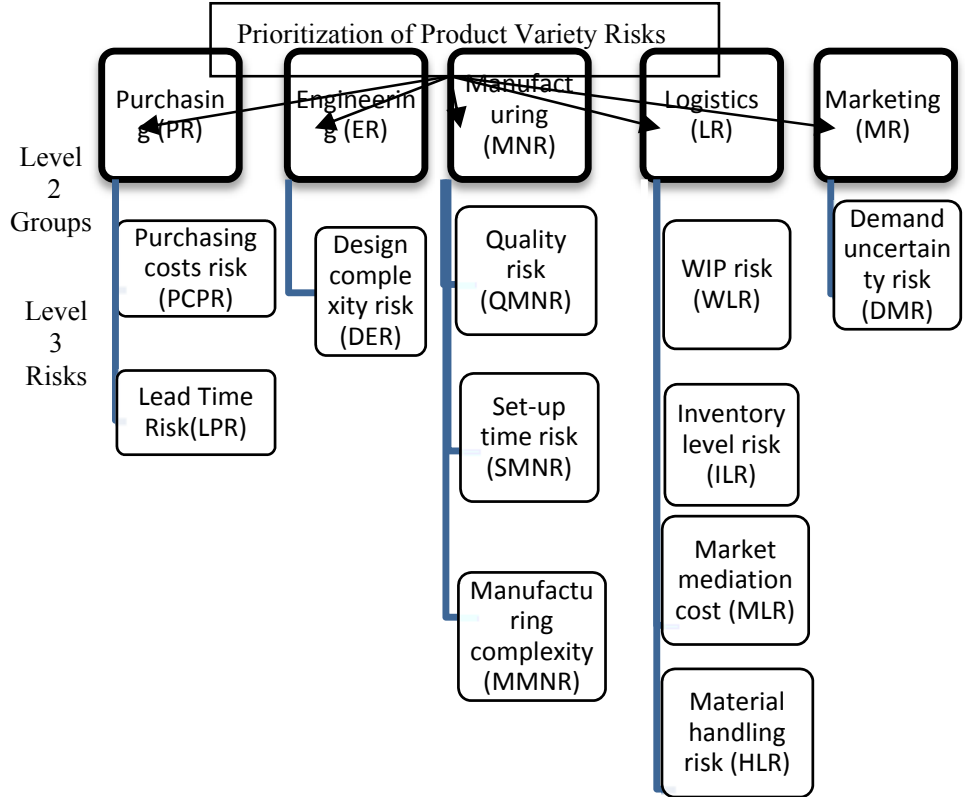

Fig. 5. A hierarchy based model of product variety risks

The second step is the pair wise comparisons that made by a questionnaire. Section 4.1 introduces the design and analysis of the questionnaire. While, Sections 4.2 describes the third and fourth steps which, calculating the weights of alternative groups (departments of the supply chain) using the methodology explained before. The same calculations are made for criteria (risks). In section 4.3 calculating the final or global weights of the risks by multiplying risk's weight by its group's weight, and priority of the risks.

\subsection{Questionnaire}

The expert's opinions are collected by distributing a designed pair wise questionnaire on sixty companies which located in 10th of Ramadan city in Egypt. This sample size was considered enough to achieve the goal of the research by getting a casual trend of the importance of the risks. Filling the questionnaire was done through direct discussion (interviews) with the supply chain manager of each company. The role of the participants is to express the degree of importance (equal importance to demonstrate importance) for each pair of groups and each pair of risks in the same group. Table 3 illustrates the pair wise comparisons between each pair of SC groups. The importance degree of each pair wise comparison is computed by taking the geometric mean of individual evaluations. Table 4 introduces the results of the questionnaire's analysis for alternative's groups after transferred it into linguistic scale. 
Table 3. Pair wise comparisons of SC groups

\begin{tabular}{|l|l|l|l|l|l|l|l|l|l|l|l|}
\hline & & & & & & & & \\
\end{tabular}

Table 4. Importance of Risk Groups

\begin{tabular}{|c|c|c|}
\hline Risks & Importance & Risks \\
\hline Marketing & $\begin{array}{l}\text { Equal to Moderate } \\
\text { Importance }\end{array}$ & Logistics \\
\hline Marketing & $\begin{array}{l}\text { Strong to Very Strong } \\
\text { Importance }\end{array}$ & Purchasing \\
\hline Marketing & $\begin{array}{l}\text { Very Strong to } \\
\text { Demonstrated } \\
\text { Importance }\end{array}$ & Engineering \\
\hline Marketing & $\begin{array}{l}\text { Moderate to Strong } \\
\text { Importance }\end{array}$ & Manufacturing \\
\hline Logistics & $\begin{array}{l}\text { Moderate to Strong } \\
\text { Importance }\end{array}$ & Purchasing \\
\hline Logistics & $\begin{array}{l}\text { Very Strong to } \\
\text { Demonstrated } \\
\text { Importance }\end{array}$ & Engineering \\
\hline Logistics & $\begin{array}{l}\text { Strong to Very Strong } \\
\text { Importance }\end{array}$ & Manufacturing \\
\hline Purchasing & $\begin{array}{l}\text { Strong to Very Strong } \\
\text { Importance }\end{array}$ & Engineering \\
\hline Manufacturing & $\begin{array}{l}\text { Moderate to Strong } \\
\text { Importance }\end{array}$ & Purchasing \\
\hline Manufacturing & $\begin{array}{l}\text { Strong to Very Strong } \\
\text { Importance }\end{array}$ & Engineering \\
\hline
\end{tabular}

\subsection{Group's weights}

The data from "Table 4" is transferred into the fuzzy comparison matrix using the triangular fuzzy scale in "Table 2" as shown in "Table 5".

Table 5. Fuzzy comparison matrix of product variety risk groups

\begin{tabular}{|r|r|c|c|cc|}
\hline & Marketing & Logistics & Purchasing & EngineeringManufacturin \\
$(\mathrm{MR})$ & $(\mathrm{LR})$ & $(\mathrm{PR})$ & $(\mathrm{ER})$ & $(\mathrm{MR})$ \\
\hline
\end{tabular}

\begin{tabular}{|c|ccc|ccc|ccc|ccc|ccc|}
\hline $\begin{array}{c}\text { Marketing } \\
(\mathrm{MR})\end{array}$ & 1 & 1 & 1 & 1 & 2 & 3 & 5 & 6 & 7 & 7 & 8 & 9 & 3 & 4 & 5 \\
\hline $\begin{array}{c}\text { Logistics } \\
\text { (LR) }\end{array}$ & $1 / 3$ & 0.5 & 1 & 1 & 1 & 1 & 3 & 4 & 5 & 7 & 8 & 9 & 5 & 6 & 7 \\
\hline $\begin{array}{c}\text { Purchasing } \\
\text { (PR) }\end{array}$ & $1 / 7$ & $1 / 6$ & $1 / 5$ & $1 / 5$ & $1 / 41 / 3$ & 1 & 1 & 1 & 5 & 6 & 7 & $1 / 5$ & $1 / 4$ & $1 / 3$ \\
\hline $\begin{array}{c}\text { Engineering } \\
\text { (ER) }\end{array}$ & $1 / 9$ & $1 / 8$ & $1 / 7$ & $1 / 9$ & $1 / 81 / 7$ & $1 / 7$ & $1 / 6$ & $1 / 5$ & 1 & 1 & 1 & $1 / 7$ & $1 / 6$ & $1 / 5$ \\
\hline $\begin{array}{c}\text { Manufacturir } \\
(\mathrm{MR})\end{array}$ & $1 / 5$ & $1 / 4$ & $1 / 3$ & $1 / 7$ & $1 / 61 / 5$ & 3 & 4 & 5 & 5 & 6 & 7 & 1 & 1 & 1 \\
\hline
\end{tabular}

From "Table 5" the weights of the product variety risk groups are calculated using fuzzy as shown in the following;

The Fuzzy synthetic values $\left(s_{i}\right)$ of the risk groups from equation (1)are:

$$
\begin{gathered}
S_{i}=\sum_{j=1}^{k} M_{i}^{j} \otimes\left[\sum_{i=1}^{n} \sum_{j=1}^{k} M_{i}^{j}\right]^{-1} \\
\sum_{i=1}^{n} \sum_{j=1}^{k} M_{i}^{j}=(50.72698,61.16667,72.08571) \\
{\left[\sum_{i=1}^{n} \sum_{j=1}^{k} M_{i}^{j}\right]^{-1}} \\
=\left(\frac{1}{72.08571}, \frac{1}{61.16667}, \frac{1}{50.72698}\right)
\end{gathered}
$$

So;

$S_{M R}=(0.2358308,0.3433248,0.492835)$

$S_{L R}=(0.2265825,0.3188016,0.4534082)$

$S_{P R}=(0.090765,0.1253408,0.1747921)$

$S_{E R}=(0.0209187,0.0258856,0.0332312)$

$S_{M N R}=(0.1296078,0.1866488,0.266788)$

Total integral value for triangular fuzzy number, $I_{i}$, (The defuzzification process) from equation (5) are:

$$
\begin{array}{r}
I_{i}^{\alpha}(M)=\frac{1}{2} \alpha(m+u)+\frac{1}{2}(1-\alpha)(1+m) \\
=\frac{1}{2}[\alpha u+m+(1-\alpha) l]
\end{array}
$$

Using $\quad \alpha=0.5$ (Sofyalıoğlu and Kartal, 2012), then;

$$
\begin{array}{ll}
I_{M R}=0.354 & I_{L R}=0.329 \quad I_{P R}=0.129 \\
I_{E R}=0.026 & I_{M N R}=0.192
\end{array}
$$

Finally the relative weights $\left(W_{i}\right)$ of the product variety risks are calculated by normalizing the indexes of optimism from equation (6);

$$
W_{i}=\frac{I_{i}}{\sum_{i=1}^{n} I_{i}}
$$




$$
\begin{gathered}
W_{M R}=\frac{0.354}{1.026}=0.345 \quad W_{L R}=\frac{0.329}{1.026}=0.32 \\
W_{P R}=\frac{0.129}{1.026}=0.125 \quad W_{E R}=\frac{0.026}{1.026}=0.025 \\
W_{M N R}=\frac{0.192}{1.026}=0.185
\end{gathered}
$$

\subsection{Prioritization of product variety risks}

Similar calculations are made for product variety risks (criteria). The findings of all the analyses are in "Table 6". Specifically, it shows (1) the weight (importance) of each supply chain risk group, (2) the weight (importance) of each product variety risk type in each group, (3) the global weight (importance) of each product variety risk, (4) and the priority of each

\begin{tabular}{|c|c|c|c|c|}
\hline $\begin{array}{l}\text { Group's } \\
\text { weight }\end{array}$ & $\begin{array}{l}\text { Product } \\
\text { variety sub- } \\
\text { risks }\end{array}$ & $\begin{array}{c}\text { Local } \\
\text { weights }\end{array}$ & $\begin{array}{l}\text { Global } \\
\text { weights } \\
\text { local weight } \\
\text { * group's weig }\end{array}$ & Priority \\
\hline \multirow[t]{2}{*}{$\begin{array}{l}\text { Purchasing } \\
(0.125)\end{array}$} & $\begin{array}{l}\text { Purchasing } \\
\text { costs }\end{array}$ & 0.2 & 0.025 & 9 \\
\hline & Lead time & 0.8 & 0.1 & 3 \\
\hline $\begin{array}{c}\text { Engineerin } \\
\mathrm{g} \\
(0.025)\end{array}$ & $\begin{array}{c}\text { Design } \\
\text { Complexity }\end{array}$ & 1 & 0.025 & 9 \\
\hline \multirow{3}{*}{$\begin{array}{l}\text { Manufactur } \\
\text { ing } \\
(0.185)\end{array}$} & $\begin{array}{l}\text { Quality } \\
\text { costs }\end{array}$ & 0.2 & 0.037 & 7 \\
\hline & Set up time & 0.5 & 0.0925 & 5 \\
\hline & $\begin{array}{l}\text { Manufacturi } \\
\text { ng } \\
\text { complexity }\end{array}$ & 0.3 & 0.0555 & 6 \\
\hline \multirow{4}{*}{$\begin{array}{l}\text { Logistics } \\
(0.32)\end{array}$} & WIP & 0.3 & 0.096 & 4 \\
\hline & $\begin{array}{c}\text { Inventory } \\
\text { level }\end{array}$ & 0.5 & 0.16 & 2 \\
\hline & $\begin{array}{c}\text { Market } \\
\text { mediation } \\
\text { cost }\end{array}$ & 0.1 & 0.032 & 8 \\
\hline & $\begin{array}{l}\text { Material } \\
\text { handling }\end{array}$ & 0.1 & 0.032 & 8 \\
\hline $\begin{array}{l}\text { Marketing } \\
(0.345)\end{array}$ & $\begin{array}{c}\text { Demand } \\
\text { uncertainty }\end{array}$ & 1 & 0.345 & 1 \\
\hline
\end{tabular}
risk which largest weight has the first priority.

Table 6. Product variety risks' global weight.

\section{Conclusion}

This paper helps in identifying and assessing the potential product variety risks that are likely to disrupt a supply chain. All product variety risks gathered based on the previous researches of the effect of product variety on the supply chain from 1985 until 2014. The risks grouped under the five basic dimensions of supply chain (Marketing, Logistic, Manufacturing, Engineering, and purchasing). Then the risks prioritized using Fuzzy Analytical Hierarchy process (FAHP).

The findings of this paper are important insights for managers of supply chain regarding product variety risks. First of all, marketing and logistics seem to be highly important as a risk group, followed by manufacturing then purchasing. On the other hand, the weight of engineering is minimal.

Demand uncertainty and inventory level have the highest priority to be mitigated. Also lead time, set up time, and WIP have high priority. The rest of risks have low weights so, mitigate them will be costly than profitably.

\section{References}

[1] Abegglen, J.C. and Stalk, G.J., KAISHA, 1985. "The Japanese Corporation", Basic Books, New York, NY.

[2] Åhlström, P. and Westbrook, R., 1999." Implications of mass customization for operations management: an exploratory survey". International Journal of Operations \& Production Management, 19(3), pp.262-275.

[3] Alford, D., Sackett, P. and Nelder, G., 2000. "Mass customisation - an automotive perspective". International Journal of Production Economics,65(1), pp.99-110.

[4] Anagnostopoulos, K.P., Gratziou, M. and Vavatsikos, A.P., 2007. "Using the fuzzy analytic hierarchy process for selecting wastewater facilities at prefecture level". European Water, 19(20), pp.15-24.

[5] Anderson, S.W., 1995. "Measuring the impact of product mix heterogeneity on manufacturing overhead cost. Accounting Review", pp.363-387.

[6] Baldwin, C.Y. and Clark, K.B., 2003. "Managing in an age of modularity.Managing in the Modular Age: Architectures, Networks, and Organizations",149.

[7] Banker, R.D., Datar, S.M., Kekre, S. and Mukhopadhyay, T., 1990." Costs of product and process complexity". Measures for manufacturing excellence, 2, pp.269-290.

[8] Bard, J.F., Gilbert, S. and Hasenbein, J., 2006. "Scheduling of product families on multiple, identical parallel production lines to minimize setup costs".

[9] Benjaafar, S., Kim, J.S. and Vishwanadham, N., 2004. "On the effect of product variety in productioninventory systems". Annals of Operations Research, 126(1-4), pp.71-101.

[10] Business Directory [http://www.businessdictionary.com/] Referenced December 12, 2014

[11] Carr, A.S. and Pearson, J.N., 2002. "The impact of purchasing and supplier involvement on strategic purchasing and its impact on firm's performance". International Journal of Operations \& Production Management, 22(9), pp.1032-1053.

[12] Chang, D.Y., 1996. "Applications of the extent analysis method on fuzzy AHP". European journal of operational research, 95(3), pp.649-655.

[13] Cooper, R. and Kaplan, R.S., 1992. Activity-based systems:" Measuring the costs of resource usage". Accounting Horizons, 6(3), pp.1-13.

[14] Crittenden, V.L., Gardiner, L.R. and Stam, A., 1993. "Reducing conflict between marketing and manufacturing". Industrial Marketing Management,22(4), pp.299-309. 
[15] De Groote, X. and Yücesan, E., 2011, December. "The impact of product variety on logistics performance". In Simulation Conference (WSC), Proceedings of the 2011 Winter (pp. 2245-2254). IEEE.

[16] Dertouzos, M.L., Lester, R.K. and Solow, R.M., 1989. "Made in America".

[17] Desai, K.K. and Trivedi, M., 2014. "Do consumer perceptions matter in measuring choice variety and variety seeking?". Journal of Business Research, 67(1), pp.2786-2792.

[18] Dictionary of Military and Associated Terms [http://www.thefreedictionary.com/]. Referenced December 12, 2014

[19] ElMaraghy, H., Schuh, G., ElMaraghy, W., Piller, F., Schönsleben, P., Tseng, M. and Bernard, A., 2013. "Product variety management. CIRP AnnalsManufacturing Technology", 62(2), pp.629-652.

[20] Er, M. and MacCarthy, B., 2006. :Managing product variety in multinational corporation supply chains: A simulation study". Journal of Manufacturing Technology Management, 17(8), pp.1117-1138.

[21] Er, M., 2004. "Managing product variety in international supply chains"(Doctoral dissertation, University of Nottingham).

[22] Federgruen, A. and Katalan, Z., 1996. "Customer waiting-time distributions under base-stock policies in single-facility multi-item production systems".Naval Research Logistics (NRL), 43(4), pp.533-548.

[23] Fisher, M, A. Jain, and J.P. MacDuffie, 1995. "Strategies for Product Variety: Lessons from the Auto Industry, in Redesigning the Firm", B. Kogut and E. Bowman eds., Oxford University Press, New York, 116-154.

[24] Fisher, M., Ramdas, K. and Ulrich, K., 1999. "Component sharing in the management of product variety: A study of automotive braking systems".Management Science, 45(3), pp.297-315.

[25] Fisher, M.L. and Ittner, C.D., 1999. "The impact of product variety on automobile assembly operations: Empirical evidence and simulation" analysis. Management science, 45(6), pp.771-786.

[26] Forza, C. and Salvador, F., 2002. "Managing for variety in the order acquisition and fulfilment process: The contribution of product configuration" systems. International journal of production economics, 76(1), pp.87-98.

[27] Fredendall, L.D. and Gabriel, T.J., 2003, April. "Manufacturing complexity: A quantitative measure". In Proc. POMS Conference (p. 2).

[28] Frizelle, G., 1996. "Getting the measure of complexity". Manufacturing Engineer 75(6): 268-270.

[29] Fujita, K., 2002. "Product variety optimization under modular architecture".Computer-Aided Design, 34(12), pp.953-965.

[30] Gupta, D. and Srinivasan, M.M., 1998. "Note: how does product proliferation affect responsiveness? ". Management Science, 44(7), pp.1017-1020

[31] Hayes, R. and Wheelwright, S., 1984. "Restoring Our Competitive Edge: Competing through Manufacturing", John Wiley \& Sons, New York, NY.

[32] Ho, T.H., Tang, C.S. and Bell, D.R., 1998. "Rational shopping behavior and the option value of variable pricing". Management Science, 44(12-part-2), pp.S145S160.

[33] Hopkin, P., 2014. "Fundamentals of risk management: understanding, evaluating and implementing effective risk management". Kogan Page Publishers.

[34] Hu, S.J., Zhu, X., Wang, H. and Koren, Y., 2008. "Product variety and manufacturing complexity in assembly systems and supply chains". CIRP AnnalsManufacturing Technology, 57(1), pp.45-48.

[35] Jaikumar, R., 1986. "Post- Industrial Manufacturing". Harvard Business Review, 64(6), 69-76.

[36] Jina, J., Bhattacharya, A.K. and Walton, A.D., 1997. "Applying lean principles for high product variety and low volumes: some issues and propositions".Logistics Information Management, 10(1), pp.5-13.

[37] Kekre, S. and Srinivasan, K., 1990. "Broader product line: a necessity to achieve success? ". Management science, 36(10), pp.1216-1232.

[38] Krishnan, V. and Gupta, S., 2001. "Appropriateness and impact of platform-based product development". Management Science, 47(1), pp.52-68.

[39] Lee, H.L. and Tang, C.S., 1997. "Modelling the costs and benefits of delayed product differentiation". Management science, 43(1), pp.40-53.

[40] MacDuffie, J.P., Sethuraman, K. and Fisher, M.L., 1996. "Product variety and manufacturing performance: evidence from the international automotive assembly plant study". Management Science, 42(3), pp.350-369.

[41] Manuj, I., Mentzer, J.T. and Bowers, M.R., 2009. "Improving the rigor of discrete-event simulation in logistics and supply chain research". International Journal of Physical Distribution \& Logistics Management, 39(3), pp.172-201

[42] Martin, M., Hausman, W. and Ishii, K., 1998. Design for variety. In Product Variety Management (pp. 103 122). Springer US

[43] Martin, M., Hausman, W. and Ishii, K., 1998. "Design for variety". In Product Variety Management (pp. 103122). Springer US.

[44] Martin, M.V. and Ishii, K., 1996, August. "Design for variety: A Methodology for Understanding Costs of Product Proliferation". In Proceedings of (pp. 18-22).

[45] Martin, M.V. and Ishii, K., 1997, September. "Design for variety: development of complexity indices and design charts". In Proceedings of (pp. 14-17)

[46] McCutcheon, D.M., Raturi, A.S. and Meredith, J.R., 1994. "The customization-responsiveness squeeze". MIT Sloan Management Review,35(2), p.89.

[47] McDermott, C.M. and Stock, G.N., 1994. "The use of common parts and designs in high-tech industries: a strategic approach". Production and Inventory Management Journal, 35(3), p.65.

[48] Miller, J.G., Vollmann, T.E. , 1985. "The Hidden Factory". Harvard Bus. Rev. 63(5), 142-150.

[49] Park, T., Velicheti, K.K., Kim, Y. and Kim, M., 2004. "THE IMPACT OF PRODUCT VARIETY ON BUSINESS OPERATIONS IN THE SUPPLY CHAIN: A LITERATURE REVIEW".

[50] Ramdas, K., Fisher, M. and Ulrich, K., 2003 "Managing variety for assembled products: Modeling component systems sharing". Manufacturing \& Service Operations Management, 5(2), pp.142-156.

[51] Randall, T. and Ulrich, K., 2001. "Product variety, supply chain structure, and firm performance: Analysis of the US bicycle industry". Management Science, 47(12), pp.1588-1604.

[52] Rao, T.H., 2008. "Quantifying the costs and benefits of product variety on key performance measures-a simulation study". ProQuest.

[53] Rau, H., Wu, M.Y. and Wee, H.M., 2003. "Integrated inventory model for deteriorating items under a multiechelon supply chain environment".International journal of production economics, 86(2), pp.155-168.

[54] Salvador, F., Forza, C. and Rungtusanatham, M., 2002. "Modularity, product variety, production volume, and component sourcing: theorizing beyond generic 
prescriptions". Journal of Operations

Management, 20(5), pp.549-575.

[55] Scott Webb, G., 2011. "Product variety: an investigation into its revenue, cost, and profit".

[56] Singhal, P., Agarwal, G. and Mittal, M.L., 2011. "Supply chain risk management: review, classification and future research directions".International Journal of Business Science and Applied Management, 6(3), pp. $15-42$.

[57] Sofyalığlu, Ç. and Kartal, B., 2012. "The selection of global supply chain risk management strategies by using fuzzy analytical hierarchy process-a case from Turkey". Procedia-Social and Behavioral Sciences, 58, pp.1448-1457.

[58] Stalk Jr, G. and Hout, T.M., 1990. "How time-based management measures performance". Planning Review, 18(6), pp.26-29.

[59] Starr, M.K., 1965. "Modular production-a new concept". Harvard business review, 43(6), pp.131-142.

[60] Tang, E.P. and Yam, R.C., 1996. "Product variety strategy-an environmental perspective". Integrated manufacturing systems, 7(6), pp.24-29.

[61] Tchankova, L., 2002. "Risk identification-basic stage in risk management.Environmental Management and Health", 13(3), pp.290-297.

[62] Thonemann, U.W. and Bradley, J.R., 2002. "The effect of product variety on supply-chain performance". European Journal of Operational Research,143(3), pp.548-569

[63] Thun, J.H. and Hoenig, D., 2011. "An empirical analysis of supply chain risk management in the German automotive industry". International Journal of Production Economics, 131(1), pp.242-249.

[64] Ton, Z. and Raman, A., 2010. "The effect of product variety and inventory levels on retail store sales: A longitudinal study". Production and Operations Management, 19(5), pp.546-560.

[65] Wan, X., 2011. "Product variety, service variety, and their impact on distributors".

[66] Wang, H., 2010. "Product variety induced complexity and its impact on mixed-model assembly systems and supply chains "(Doctoral dissertation, General Motors).

[67] Wang, Y.M., Luo, Y. and Hua, Z., 2008. "On the extent analysis method for fuzzy AHP and its applications". European Journal of Operational Research, 186(2), pp.735-747.

[68] Whang, S. and Lee, H., 1998. "Value of postponement". In Product Variety Management (pp. 65-84). Springer US.

[69] Wind, Y. and Saaty, T.L., 1980. "Marketing applications of the analytic hierarchy process". Management science, 26(7), pp.641-658.

[70] Yayla-Kullu, H.M., 2009. "Product line design under capacity and competition"(Doctoral dissertation, THE UNIVERSITY OF NORTH CAROLINA AT CHAPEL HILL).

[71] Yeh, K.H. and Chu, C.H., 1991. "Adaptive strategies for coping with product variety decisions". International journal of operations \& production management, 11(8), pp.35-47.

[72] Yu, C.S., 2002. "A GP-AHP method for solving group decision-making fuzzy AHP problems". Computers \& Operations Research, 29(14), pp.1969-2001.

[73] Zhang, F., 2006." A note on supply risk and inventory outsourcing". Production Planning \& Control, 17(8), pp.796-806.

[74] Zhenxin Yu, 2006. "Essay on product variety and supply chain management: product line, pricing capacity, and inventory choices".
[75] Zhu, X., 2009." Modeling product variety induced manufacturing complexity for assembly system design" (Doctoral dissertation, General Motors). 